\title{
Eckol inhibits Reg3A-induced proliferation of human SW1990 pancreatic cancer cells
}

\author{
MENGYA ZHANG ${ }^{1,2^{*}}$, WEIPING ZHOU ${ }^{1,2^{*}}$, SHUQI ZHAO $^{1,2}$, SHULAN LI $^{1,2}$, DAN YAN ${ }^{1,2}$ and JUN WANG ${ }^{1,2}$ \\ ${ }^{1}$ Hubei Province Key Laboratory of Occupational Hazard Identification and Control; \\ ${ }^{2}$ New Medicine Innovation and Development Institute, Department of Pharmacy, College of Medicine, \\ Wuhan University of Science and Technology, Wuhan, Hubei 430065, P.R. China
}

Received November 26, 2018; Accepted June 27, 2019

DOI: $10.3892 /$ etm.2019.7889

\begin{abstract}
Pancreatic cancer $(\mathrm{PaC})$ is characterized by a highly inflammatory tumor microenvironment, and inflammatory mediators are implicated in the progression of this cancer. Regenerating gene protein (Reg) 3A is significantly upregulated during pancreatic inflammation, and has been demonstrated to serve an important role during $\mathrm{PaC}$ progression, based on its increased expression levels in $\mathrm{PaC}$ and potent cell proliferation-promoting activity. The aim of the present study was to investigate the effect of eckol, a phlorotannin compound with a variety of biological activities including anti-inflammatory, anti-tumor and cytoprotective effects, on Reg3A-induced proliferation of human SW1990 PaC cells. SW1990 cells were pre-treated with eckol for $48 \mathrm{~h}$ at concentrations of 5, 10 and $20 \mu \mathrm{g} / \mathrm{ml}$. Subsequently, Reg3A protein was added to the culture media at a final concentration of $50 \mathrm{ng} / \mathrm{ml}$ in the presence or absence of eckol for $24 \mathrm{~h}$. The cytotoxicity and proliferative capacity of the SW1990 cells was determined using an MTT and flow cytometry analysis. Cell colony formation was also used to determine the effect of eckol on the anchorage-independent growth and colony-forming capacity of Reg3A-treated PaC cells. The expression levels of cyclin D1, STAT3, JAK2, and NF- $\kappa$ B p65 were measured with reverse transcription-quantitative PCR and western blotting. Eckol reduced Reg3A-promoted cell survival, inhibited Reg3A-induced cell cycle progression and inhibited colony growth of SW1990 cells in soft agar in a concentration-dependent manner. Additionally, the Reg3A-mediated upregulation of expression of JAK2, STAT3,
\end{abstract}

Correspondence to: Dr Jun Wang, Hubei Province Key Laboratory of Occupational Hazard Identification and Control, Wuhan University of Science and Technology, 2 Hangjiahu West Road, Wuhan, Hubei 430065, P.R. China

E-mail:wangj79@hotmail.com

*Contributed equally

Key words: eckol, Reg3A, pancreatic cancer, inflammation, proliferation
$\mathrm{NF}-\kappa \mathrm{Bp} 65$ and cyclin D1 was reduced when treated with eckol. Reg3A is upregulated during pancreatic inflammation and exhibits a pro-growth function and may thus serve a critical role during inflammation-driven $\mathrm{PaC}$ malignancies. Eckol may be a potential protective agent against progression of $\mathrm{PaC}$ accompanied by pancreatic inflammation.

\section{Introduction}

Pancreatic cancer $(\mathrm{PaC})$, known as the king of carcinoma, is a type of highly lethal malignant tumor with high rate of incidence around the world (1). The 5-year relative survival rate of $\mathrm{PaC}$ is $<8 \%$, due to its rapid progression, asymptomatic development, poor prognosis and the relative lack of effects of treatment (2). The etiology and pathogenesis of $\mathrm{PaC}$ still remains unclear. However, regenerating gene protein (Reg) 3A has been generally accepted to serve an important role during pancreatic carcinogenesis and $\mathrm{PaC}$ progression, based on its high expression in $\mathrm{PaC}$ and tumor-promoting activity (3-6). Reg proteins are members of the calcium-dependent $\mathrm{C}$-type lectin family, which have been characterized as promoters of proliferation and differentiation in a range of cell types (7). In humans, 5 Reg family proteins including Reg1A, Reg1B, Reg3A, Reg3G and Reg4 have been identified (4). Among them, Reg3A is selectively expressed in the pancreas and small intestine (8). During pancreatic inflammation, Reg3A expression is significantly increased and has thus also been named pancreatitis-associated protein $(5,6)$. Elevated concentrations or expression of Reg3A in pancreatic juice/serum $(9,10)$ or tumor tissues $(5,6)$ have been reported in patients with $\mathrm{PaC}$. Reg3A may promote the survival, proliferation, growth of $\mathrm{PaC}$ cells and acinar-to-ductal metaplasia formation, and overexpression of Reg3A in $\mathrm{PaC}$ is significantly associated with the aggressiveness of the tumor $(5,6)$. Therefore, during pancreatic inflammation-mediated upregulation of Reg3A, Reg3A may function as an oncogene to promote the development and progression of $\mathrm{PaC}$.

Although $\mathrm{PaC}$ therapies, including surgical resection, chemotherapy and radiotherapy have improved over a number of decades, the outcomes of patients with $\mathrm{PaC}$ have not improved significantly (11). Therefore, there is an need urgent to develop alternative therapeutic approaches which may improve control of the aggressiveness of $\mathrm{PaC}$. Novel therapies 
based on natural products with minimal toxicity have been demonstrated to benefit patients with $\mathrm{PaC}(11,12)$.

Eckol, a phlorotannin component isolated from brown algae, is a marine natural product with a variety of potent biological activities (13). For example, eckol has been demonstrated to exhibit antioxidant and cytoprotective properties (14-17), neuroprotective effect (18-20) and anti-adipogenic activities (21). Additionally, eckol is also a well-known anti-inflammatory agent. Jung et al (22) demonstrated that eckol could inhibit lipopolysaccharide (LPS)-induced nitric oxide production in RAW264.7 macrophages in a dose-dependent manner. In HepG2 cells, eckol significantly inhibited LPS-stimulated inflammatory responses without any cytotoxicity (23). A few previous studies have demonstrated the cytotoxic effects of eckol against tumors $(24,25)$. As the source of eckol, brown algae has long been considered to exhibit relatively higher anti-tumor activities compared with other algae (24). Hyun et al (25) reported that eckol treatment decreased the tumorigenic capacity of glioma cells, and sensitized these cell to established anticancer treatments, suggesting a novel potential adjuvant capacity of eckol for treating patients with cancer. However, the effect of eckol on $\mathrm{PaC}$ has not been investigated, to the best of our knowledge.

Based on the role of pancreatic inflammation-upregulated Reg3A in $\mathrm{PaC}$ progression, together with the existing evidence that eckol has potential anti-inflammatory and anti-tumor effects, eckol may inhibit Reg3A-induced proliferation of $\mathrm{PaC}$ cells, and thus protect against progression of inflammation-associated $\mathrm{PaC}$. To test this hypothesis, the effect of eckol on the proliferation of Reg3A-stimulated human SW1990 PaC cells was determined. Human pancreatic adenocarcinoma cell line SW-1990 is a representative and common $\mathrm{PaC}$ cell line with aggressive behaviors $(5,6)$. A previous study studied the effect of Reg3A on the proliferation of five different $\mathrm{PaC}$ cell lines; AsPC-1, Mia Paca-2, BxPC-3, SW1990, PANC-1 (6). The results showed that the proliferation-promoting effect of Reg3A was most marked in the SW1990 cells, that is, SW1990 was the most sensitive cell line to exogenous Reg3A stimulation amongst the studied cell lines. The aim of the present study was to determine whether eckol may potentially limit the malignant development of $\mathrm{PaC}$ driven by pancreatic inflammatory mediators such as Reg3A, a pancreatic inflammation-upregulated protein with pro-growth function.

\section{Materials and methods}

Cell culture and treatment. The human PaC cell line, SW1990 was obtained from American Type Culture Collection (American Type Culture Collection) was cultured in $5 \% \mathrm{CO}_{2}$ atmosphere at $37^{\circ} \mathrm{C}$ in RPMI 1640 (Hyclone; GE Healthcare Life Sciences) supplemented with $10 \%$ fetal calf serum and 100 units/ml penicillin/streptomycin (both Invitrogen; Thermo Fisher Scientific, Inc.). SW1990 cells were pre-treated with eckol (Rongbao Environmental Technology Co., Ltd) for $48 \mathrm{~h}$ with 5, 10 and $20 \mu \mathrm{g} / \mathrm{ml}$. Subsequently, Reg3A protein (Sino Biological Inc.) was added to the culture media at a final concentration of $50 \mathrm{ng} / \mathrm{ml}$ in the presence or absence of eckol for $24 \mathrm{~h}$. The control cells were treated with the same volume of vehicle (DMSO).
Cytotoxicity assay. The cytotoxic effects of eckol on SW1990 cells was determined using an MTT assay as described previously (26). Briefly, 4x103 SW1990 cells were plated per well in a 96 well microplates and pre-incubated for $24 \mathrm{~h}$. Subsequently, the cells were treated with Reg3A and/or eckol as described above, after which $20 \mu 15 \mathrm{mg} / \mathrm{ml}$ MTT (Sigma-Aldrich; Merck $\mathrm{KGaA}$ ) was added to each well and the plates were incubated at $37^{\circ} \mathrm{C}$ for a further $4 \mathrm{~h}$. The survival rate of SW1990 cells was calculated as the A570 of treated cells/A570 of control cells. There were a total of 8 wells per condition.

Cell cycle assay. Following treatment with Reg3A and/or eckol, the SW1990 cells were stained with propidium iodide (PI; Sigma-Aldrich; Merck KGaA) at $4^{\circ} \mathrm{C}$ for $30 \mathrm{~min}$, and immediately analyzed using a Flow Cytometer and CellQuest Pro software version 5.1 (both BD Biosciences).

Colony formation in soft agarose. Following treatment with Reg3A and/or eckol, the SW1990 cells were seeded in 6-well plates at a density of 500 cells per well with five replicates, and incubated for 2 weeks for the colony formation assay in soft agarose culture as described previously $(5,6)$. RPMI 1640 medium (X2 concentration) was mixed with an equal volume of $1.2 \%$ melted agarose (Invitrogen; Thermo Fisher Scientific, Inc.) to prepare the agar. The number of colonies formed per 100 seeded SW1990 cells was assessed by counting under a compound light microscope at a magnification of x100.

Reverse transcription-quantitative $(R T-q) P C R$. Total RNA was isolated from the cells using TRIzol ${ }^{\circledR}$ Reagent (Invitrogen; Thermo Fisher Scientific, Inc.). The mRNAs were reverse-transcribed to cDNAs using a PrimeScript ${ }^{\circledR}$ RT Master mix (Perfect Real Time; Takara Bio, Inc.) under the reaction conditions of $37^{\circ} \mathrm{C}$ for $15 \mathrm{~min}$ and $85^{\circ} \mathrm{C}$ for $5 \mathrm{sec}$. RT-qPCR was performed using an Applied Biosystems StepOnePlus ${ }^{\mathrm{TM}}$ system using a SYBR Green Premix kit (Takara Bio Inc.) as the fluorophore. Primers were as follows: Cyclin D1 forward, 5'-TCTACACCGACAACTCCATCCG-3' and reverse, 5'-TCT GGCATTTTGGAGAGGAAGTG-3'; STAT3 forward, 5'-CCC ATCCAGGCTGAGTATGT-3' and reverse, 5'-GATCCAGTC CGTGGAACCAT-3'; JAK2 forward, 5'-CCTTGTACTTCA CGATGTTGTC-3' and reverse, 5'-GTGGAGATGTGCCGC TATG-3'; NF-кB p65 forward, 5'-CTTCAGAATGGCAGA AGATGA-3' and reverse, 5'-CACATACATAACGGAAAC GAAA-3'; $\beta$-actin forward, 5'-TCACCCACACTGTGCCCA TCTACGA-3' and reverse, 5'-CAGCGGAACCGCTCATTG CCAATGG-3'. The thermocycling conditions were: i) $95^{\circ} \mathrm{C}$ For $10 \mathrm{~min}$; and ii) 40 cycles of $95^{\circ} \mathrm{C}$ for $30 \mathrm{sec}, 58^{\circ} \mathrm{C}$ for $30 \mathrm{sec}$ and $72^{\circ} \mathrm{C}$ for $30 \mathrm{sec}$. The mRNA levels of cyclin D1, STAT3, JAK2, and NF- $\kappa$ B p65 were normalized to those of $\beta$-actin. The results were analyzed using the $2^{-\Delta \Delta \mathrm{Cq}}$ method (27).

Western blotting. The protein expression levels of Cyclin D1, STAT3, JAK2 and NF-кB p65 were detected by western blotting. The total protein in the SW1990 cells was extracted using RIPA lysis and extraction buffer containing protease inhibitor cocktail (Pierce; Thermo Fisher Scientific, Inc.). A bicinchoninic acid protein assay kit (Pierce; Thermo Fisher Scientific, Inc.) was used to determine the protein concentration of each sample. Equal quantities of protein (50 $\mu \mathrm{g}$ per lane) were 


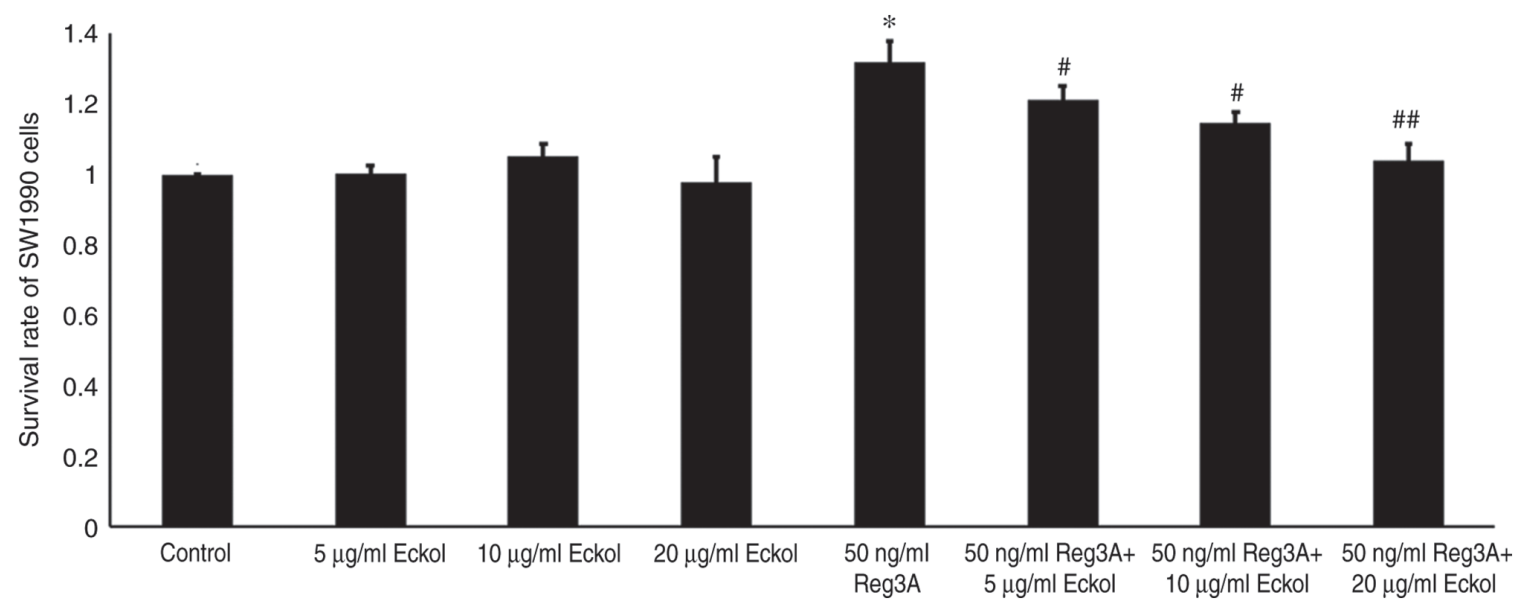

Figure 1. Effect of eckol on Reg3A-promoted SW1990 cell survival. The cell viability of human SW1990 pancreatic cancer cells was assessed using an MTT assay ( $\mathrm{n}=8)$. ${ }^{\prime} \mathrm{P}<0.05$ vs. the control group; ${ }^{~} \mathrm{P}<0.05,{ }^{\# \#} \mathrm{P}<0.01$ vs. the $50 \mathrm{ng} / \mathrm{ml}$ Reg3A group.

resolved by SDS-PAGE on a $12 \%$ gel and transferred onto a nitrocellulose membrane by electroblotting. The membrane was blocked overnight at $4^{\circ} \mathrm{C}$ with $5 \%$ skimmed milk in TBST (20 $\mathrm{mM}$ Tris- $\mathrm{HCl}, 0.1 \%$ Tween-20 and $150 \mathrm{mM} \mathrm{NaCl}$ ) and subsequently incubated at $37^{\circ} \mathrm{C}$ for $2 \mathrm{~h}$ with a $1: 1,000$ dilution of rabbit monoclonal anti-human phosphorylated (p)STAT3 (cat. no. 9145), pJAK2 (cat. no. 4406), STAT3 (cat. no. 4904), JAK2 antibody (cat. no. 3230; all form CST Biological Reagents Co., Ltd.), rabbit monoclonal anti-human CyclinD1 antibody (cat. no. ab16663; Abcam), rabbit monoclonal NF- $\mathrm{B}$ p65 antibody (cat. no. AP3749a; Abgent, Inc.) or mouse monoclonal anti- $\beta$-actin antibody (cat. no. sc-47778; Santa Cruz Biotechnology Inc.). Horseradish peroxidase-conjugated sheep anti-rabbit or anti-mouse immunoglobulin $\mathrm{G}$ (cat. nos. LK2001L or LK2003L; Tianjin Sungene Biotech Co., Ltd.) was used as the secondary antibody. After incubation with the corresponding secondary antibody at a dilution of 1:2,000 for $2 \mathrm{~h}$ at room temperature, signals were visualized using an enhanced chemiluminescence detection kit (Advansta, Inc.) and scanned using an EPSON Perfection V370 Photo Scanner (Seiko Epson Corporation). Densitometric analysis of the image was performed using ImageJ (version 1.8.0; National Institutes of Health). Protein expression was normalized to the amount of $\beta$-actin in the same sample.

Statistical analysis. The statistical analyses were performed using SPSS version 12.0 (SPSS, Inc., Chicago, IL, USA). Data are expressed as the mean \pm standard deviation of at least five repeats. The statistical significance of difference between groups was determined using a one-way ANOVA followed by a post-hoc Tukey's test. $\mathrm{P}<0.05$ was considered to indicate a statistically significant difference.

\section{Results}

Eckol decreases Reg3A-induced SW1990 cell survival. The direct effect of eckol on the survival of human SW1990 $\mathrm{PaC}$ cells was determined by treating cells with 5,10 or $20 \mu \mathrm{g} / \mathrm{ml}$ eckol for $72 \mathrm{~h}$. The treatment of SW1990 cells with $5-20 \mu \mathrm{g} / \mathrm{ml}$ eckol did not result in a significant change in cell viability as determined by an MTT assay (Fig. 1).
Cells treated with $50 \mathrm{ng} / \mathrm{ml}$ exogenous Reg3A protein demonstrated a $31.8 \%$ increase in survival compared with the control $(\mathrm{P}<0.05$; Fig. 1). Cell survival was significantly decreased in SW1990 cells treated with $50 \mathrm{ng} / \mathrm{ml} \mathrm{Reg3A}$ and 5,10 or $20 \mu \mathrm{g} / \mathrm{ml}$ eckol by $10.2,16.5$, and $22.9 \%$, respectively, when compared with cells treated with Reg3A alone $(5 \mu \mathrm{g} / \mathrm{ml}, \mathrm{P}<0.05 ; 10 \mu \mathrm{g} / \mathrm{ml}, \mathrm{P}<0.05 ; 20 \mu \mathrm{g} / \mathrm{ml}, \mathrm{P}<0.01)$. Therefore, these data suggest that $5-10 \mu \mathrm{g} / \mathrm{ml}$ eckol did not have a significant direct cytotoxic effect on human SW1990 $\mathrm{PaC}$ cells, however, attenuated the Reg3A-mediated increase in SW1990 cell survival.

Eckol attenuates Reg3A-induced cell cycle progression in human SW1990 PaC cells. Based on the above preliminary assays, the effect of eckol on the cell cycle progression in cells treated with and without Reg3A was determined using flow cytometry analysis. As shown in Fig. 2, incubation with exogenous Reg3A for $24 \mathrm{~h}$ caused a significantly lower number of cells in the G0/G1 phase and the accumulation of cells in the $\mathrm{G} 2 / \mathrm{M}$ and $\mathrm{S}$ phases, compared with the control group $(\mathrm{P}<0.01)$. However, treatment of cells with Reg3A and eckol resulted in the reduction in the number of cells in the G2/M and S phases, and the increase in the proportion of cells in the G0/G1 phase, particularly at with 10 and $20 \mu \mathrm{g} / \mathrm{ml}(\mathrm{P}<0.05, \mathrm{P}<0.01$, respectively) when compared with cells treated with $\operatorname{Reg} 3 \mathrm{~A}$ only. The data in Fig. 2 suggest that eckol may attenuate the proliferation-promoting effect of Reg3A on human SW1990 $\mathrm{PaC}$ cells.

Eckol attenuates Reg3A-mediated SW1990 PaC cell colony formation in soft agar. SW1990 cells were seed in soft agar to determine the effect of eckol on the anchorage-independent growth and colony-forming capacity of Reg3A-treated PaC cells. As shown in Fig. 3, SW1990 cells formed colonies in soft agar, and Reg3A incubation for $24 \mathrm{~h}$ significantly enhanced the colony growth $(\mathrm{P}<0.01$ compared with control). Compared with the cells incubated with exogenous Reg3A alone, fewer colonies were observed in cells treated with Reg3A in combination with 10 or $20 \mu \mathrm{g} / \mathrm{ml}$ eckol $(\mathrm{P}<0.05)$, suggesting that eckol may decrease Reg3A-mediated anchorage-independent SW1990 PaC cell growth. 

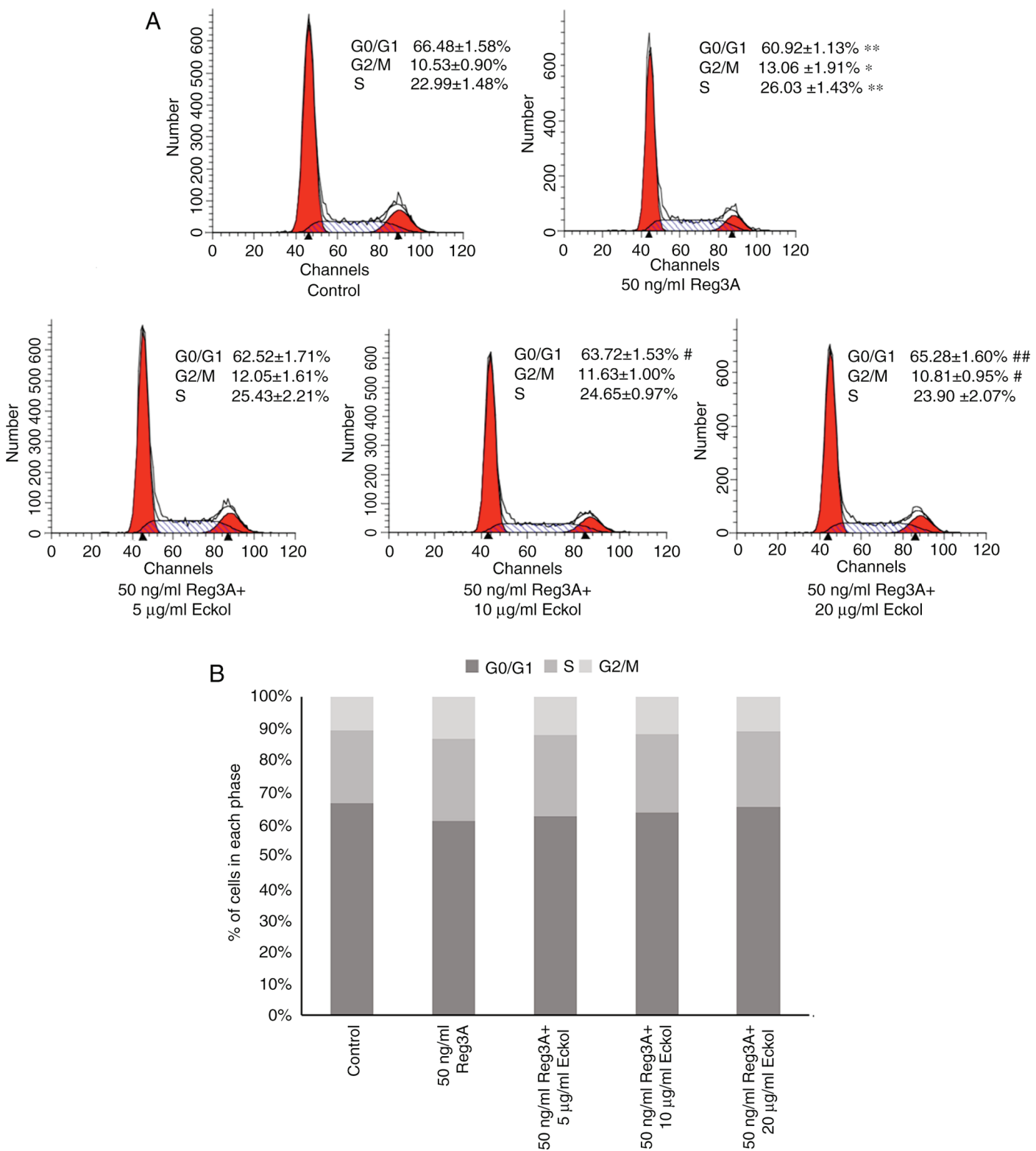

Figure 2. Effect of eckol on Reg3A-induced cell cycle progression of human SW1990 pancreatic cancer cells. The cell cycle distribution of SW1990 cells were analyzed by flow cytometry staining with propidium iodide. (A) Representative flow cytometry data. (B) Percentage of cells at each phase of the cell cycle $(\mathrm{n}=5) .{ }^{*} \mathrm{P}<0.05,{ }^{* *} \mathrm{P}<0.01$ vs. the control group; ${ }^{\#} \mathrm{P}<0.05,{ }^{\# \#} \mathrm{P}<0.01$ vs. the $50 \mathrm{ng} / \mathrm{ml}$ Reg3A group.

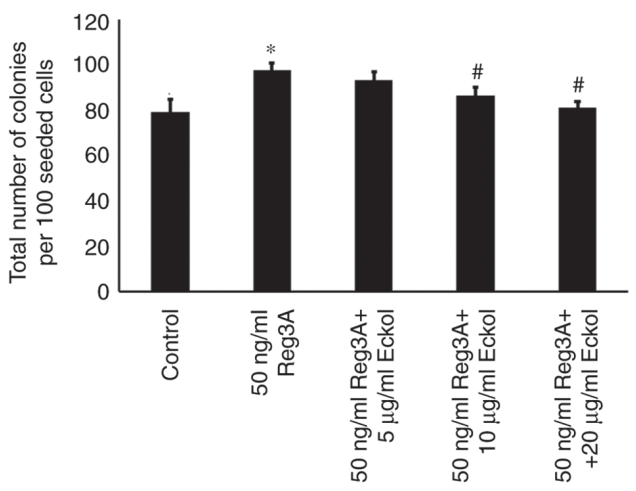

Figure 3. Effect of eckol on Reg3A-promoted SW1990 PaC cell colony formation in soft agar. The treated cells were cultured in soft agar for 3 weeks and stained with MTT for observation. Colonies formed of $>50$ cells were scored under an inverted microscope, and the number of colonies formed per 100 seeded SW1990 cells was assessed $(n=5)$. "P<0.05 vs. the control group; ${ }^{\#} \mathrm{P}<0.05$ vs. the $50 \mathrm{ng} / \mathrm{ml} \mathrm{Reg} 3 \mathrm{~A}$ group.
$J A K / S T A T 3$ and $N F-\kappa B /$ cyclin D1 pathways may contribute to the protective effect of eckol on Reg3A-induced over-proliferation of SW1990 PaC cells. Based on the above results, the possible underlying molecular mechanism involved in the protective effects of eckol on Reg3A-induced over-proliferation of SW1990 PaC cells were determined using RT-qPCR and western blot analysis of Reg3A signaling-associated molecules, including JAK2, STAT3, NF- $\mathrm{KB}$ and cyclin D1. As shown in Fig. 4, administration of $50 \mathrm{ng} / \mathrm{ml}$ exogenous Reg3A for $24 \mathrm{~h}$ significantly upregulated the expression of JAK2 $(\mathrm{P}<0.01)$, STAT3 $(\mathrm{P}<0.05), \mathrm{NF}-\kappa \mathrm{B}(\mathrm{P}<0.01)$ and cyclin D1 $(\mathrm{P}<0.01)$ in SW1990 cells. The addition of varying concentrations of eckol reduced the Reg3a-induced increases in JAK2, STAT3, NF- $\kappa \mathrm{B}$ and cyclin D1 mRNA expression levels. Compared with the cells incubated with Reg3A alone, eckol treatment decreased the activation of JAK2 $(20 \mu \mathrm{g} / \mathrm{ml}$ eckol; $\mathrm{P}<0.05)$ and STAT3 (10 and $20 \mu \mathrm{g} / \mathrm{ml}$ eckol; both $\mathrm{P}<0.05$ ) in SW1990 

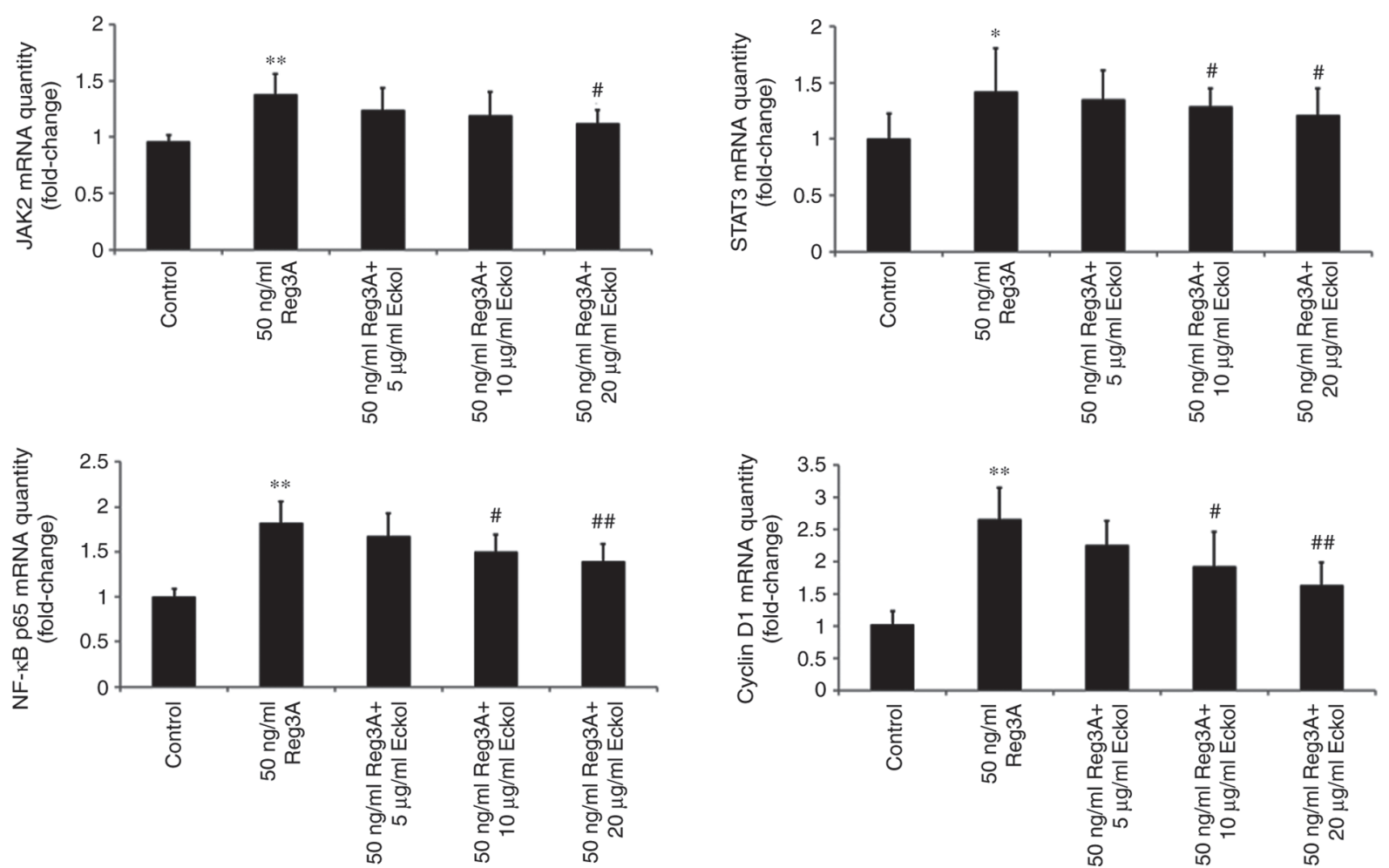

Figure 4. Eckol downregulates Reg3A-induced mRNA expression of JAK2, STAT3, NF- $\kappa$ B p65 and Cyclin D1. Reverse transcription-quantitative PCR was used to measure the mRNA expression levels of JAK2, STAT3, NF- $\kappa$ B p65 and CyclinD1 in the total cell lysate of SW1990 cells $(\mathrm{n}=5)$. ${ }^{*} \mathrm{P}<0.05,{ }^{* * *} \mathrm{P}<0.01 \mathrm{vs}$. the control group; ${ }^{\#} \mathrm{P}<0.05,{ }^{\# \#} \mathrm{P}<0.01$ vs. the $50 \mathrm{ng} / \mathrm{ml}$ Reg3A group.

cells. Additionally, $10 \mu \mathrm{g} / \mathrm{ml}(\mathrm{P}<0.05)$ and $20 \mu \mathrm{g} / \mathrm{ml}(\mathrm{P}<0.01)$ eckol reduced the mRNA expression levels of both $\mathrm{NF}-\kappa \mathrm{B}$ and Cyclin D1. Compared with cells incubated with Reg3A alone, $>10 \mu \mathrm{g} / \mathrm{ml}$ eckol treatment decreased the phosphorylation of JAK2/STAT3 and protein expression levels of NF- $\kappa$ B/cyclin D1 in SW1990 cells treated with Reg3A. The data in Figs. 4 and 5 suggest that the protective effect of eckol on Reg3A-induced over-proliferation may be associated with the JAK/STAT3 and $\mathrm{NF}-\kappa \mathrm{B} /$ cyclin D1 signaling pathways in human $\mathrm{PaC}$.

\section{Discussion}

The association between inflammation and cancer is well-known and researched (28). Inflammation is considered a hallmark and a dominant feature of cancer (28). Evidence has shown that almost all tumors possess an inflammatory tumor microenvironment (28). In $\mathrm{PaC}$, there is an indispensable contribution of pre-existing inflammation to pancreatic carcinogenesis, which frequently manifests as a chronic inflammatory response to pancreatic diseases such as chronic pancreatitis, hereditary pancreatitis, and is a contributing risk factors in patients with $\mathrm{PaC}$ (29). Furthermore, $\mathrm{PaC}$ is characterized by a highly inflammatory tumor microenvironment, and inflammatory mediators are implicated in the progression of this tumor (30). Sustained inflammation within $\mathrm{PaC}$ tissues aggravates the behavior of cancer cells (such as cell proliferation and survival), affects the tumor microenvironment, and is conducive to the invasive growth of $\mathrm{PaC}$ (29,31). During the progression of $\mathrm{PaC}$, additional inflammatory cells are recruited into the cancer microenvironment and the interaction between cancer-associated inflammation and tumor cells promotes the malignant progression of $\mathrm{PaC}$ (32).

The molecular events involved in inflammation-associated cancer have been gradually uncovered (3-6,28-31). IL-6 has long been demonstrated as a well-known mediator involved in inflammation-associated pancreatic carcinogenesis $(5,6)$. There is a synergistic effect of Reg3A and IL-6 on PaC development (5). As a mediator induced by pancreatic inflammation and a promoter of cancer cell growth in $\mathrm{PaC}$, Reg3A serves an important role in the progression of $\mathrm{PaC}$ accompanied by pancreatic inflammation (3-6). Reg3A has been demonstrated to be overexpressed in $79 \%$ (30 out of 38) of pancreatic tissues from individuals with $\mathrm{PaC}(10)$. In a cohort of 36 patients who underwent resection for $\mathrm{PaC}(6)$, Reg3A mRNA expression levels in tumor tissues were significantly higher in the patients with inflammation history, in tumors $>3 \mathrm{~cm}$, in relatively undifferentiated tumors and in patients in Tumor-Node-Metastasis stage III-IV, indicating the association between the inflammatory mediator Reg3A and $\mathrm{PaC}$ malignancy.

In line with previous studies $(5,6), 50 \mathrm{ng} / \mathrm{ml}$ exogenous Reg3A promoted cell growth, proliferation and tumor formation in human SW1990 PaC cells. In the present study, despite the fact that cell viability as assessed by MTT assay was not significantly influenced by eckol, there was a reduction in Reg3A-induced cell survival, the proportion of cells in the G2/M and S phases and the colony-forming ability of cells in eckol-treated SW1990 cells. The protective role of eckol in normal tissue cells has been well documented (25). 
A

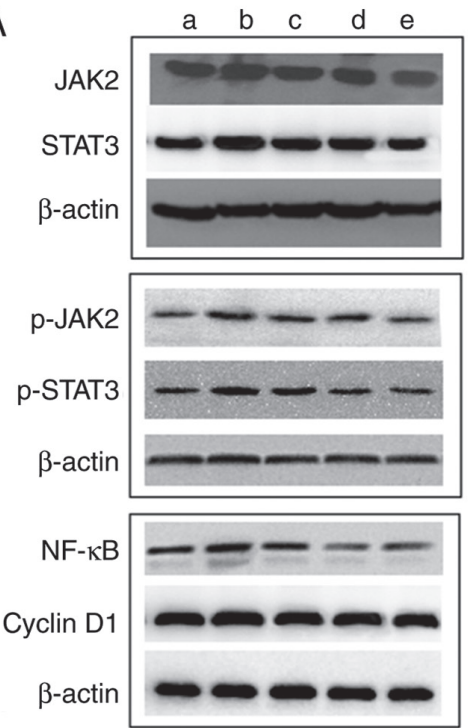

a: Control

b: $50 \mathrm{ng} / \mathrm{ml} \operatorname{Reg} 3 \mathrm{~A}$

c: $50 \mathrm{ng} / \mathrm{ml}$ Reg $3 \mathrm{~A}+5 \mu \mathrm{g} / \mathrm{ml}$ Eckol

d: $50 \mathrm{ng} / \mathrm{ml}$ Reg3A+10 $\mu \mathrm{g} / \mathrm{ml}$ Eckol

e: $50 \mathrm{ng} / \mathrm{ml}$ Reg3A+20 $\mu \mathrm{g} / \mathrm{ml}$ Eckol
B
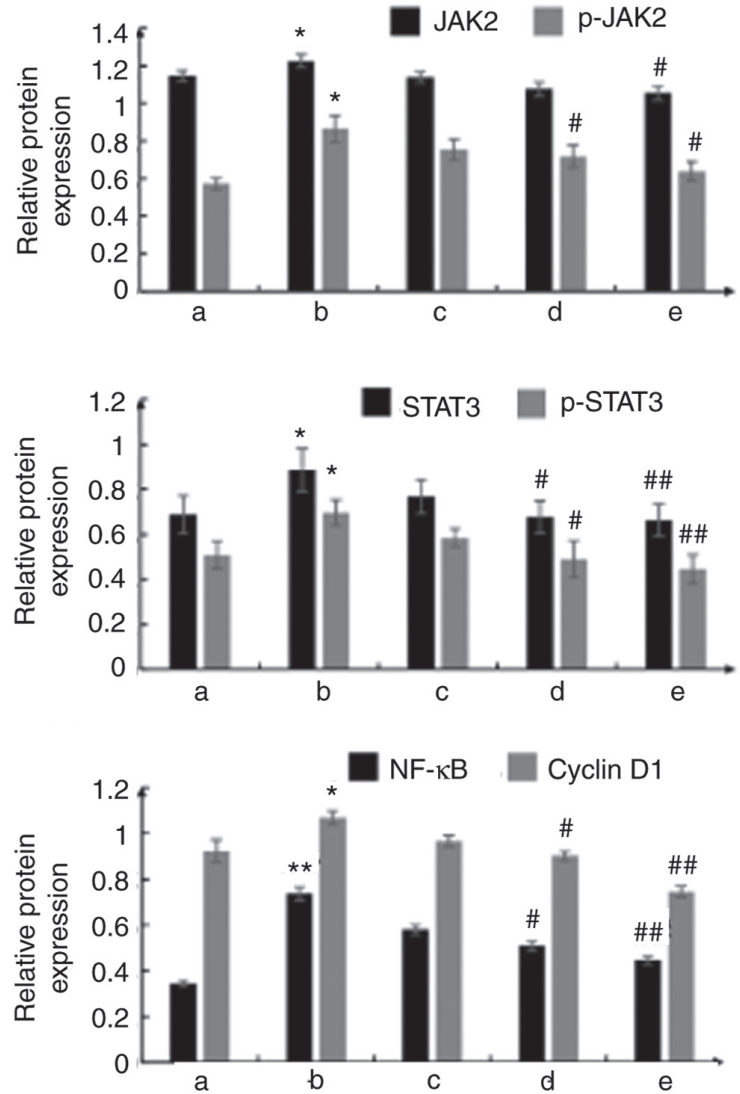

Figure 5. Effect of eckol on the protein expression and phosphorylation levels of JAK2/p-JAK2, STAT3/p-STAT3, NF- $\mathrm{BB}$ and CyclinD1 in SW1990 cells treated with Reg3A. Cells treated with eckol for $48 \mathrm{~h}$ after which $50 \mathrm{ng} / \mathrm{ml}$ exogenous Reg3A was added to induce proliferation for $24 \mathrm{~h}$. Total protein was extracted from the cells and western blotting was used to measure the protein expression levels. (A) Representative bands were cropped from different gels for repeated experiments. (B) Relative expression of proteins were normalized against $\beta$-actin $(\mathrm{n}=5)$. ${ }^{*} \mathrm{P}<0.05,{ }^{* *} \mathrm{P}<0.01 \mathrm{vs}$. the control group; ${ }^{\#} \mathrm{P}<0.05$, ${ }^{\# \#} \mathrm{P}<0.01 \mathrm{vs}$. the $50 \mathrm{ng} / \mathrm{ml}$ Reg3A group. p-, phosphorylated.

Eckol was previously found to exhibit cytoprotective activity in hepatocytes (17), neurocytes $(18,19)$, keratinocytes (33) and lung fibroblast cells (34). In addition, eckol showed hepatoprotective activity in tacrine-treated in HepG2 cells (15). Hyun et al (25) reported that treatment of glioma cells cultured in sphere forming condition, induced with epidermal growth factor and basic fibroblast growth factor, with $50 \mu \mathrm{M}$ eckol significantly decreased cell proliferation and the formation of spheres and there was no significant increase in cell death when treated with 10-80 $\mu \mathrm{M}$ eckol. These previous studies suggest that eckol appears to exert dual regulatory effects on cell proliferation and viability. In the present study, eckol treatment inhibited the Reg3A-induced increase in proliferation without decreasing the viability of SW1990 cells. Therefore, eckol may be a safe compound for controlling the progression of $\mathrm{PaC}$ accompanied by pancreatic inflammation, which possesses activity against inflammation-driven $\mathrm{PaC}$ malignancies without significantly affecting the cell viability.

The JAK2/STAT3 signal transduction pathway is closely associated with Reg3A-mediated $\mathrm{PaC}$ cell growth $(5,6)$. The JAK2/STAT3 signaling pathway is an important pathway in a wide variety of malignant diseases including $\mathrm{PaC}$ (35) and is required for expression of Reg3A in response to the stimulation of proinflammatory factors (such as IL-6) $(4,6)$. In the present study it was demonstrated that, Reg3A regulated the activation of JAK2 and STAT3, which is in agreement with Wang et al (6) and Liu et al (5). Therefore, there may be crosstalk between Reg3A and JAK2/STAT3 signaling, forming a positive feedback loop, ultimately promoting $\mathrm{PaC}$ development (5). In addition, STAT3 co-operates with $\mathrm{NF}-\kappa \mathrm{B}$, another key molecule associated with malignant conversion and progression (36) by promoting cell proliferation, transformation and tumor development (37). Cyclin D1 is one of important transcriptional targets of NF- $\kappa \mathrm{B}$ which contributes to cell cycle progression (38). Acceleration of the G1/S transition via regulation of the cell-cycle-associated protein cyclin D1 represents a key mechanism by which $\mathrm{NF}-\kappa \mathrm{B}$ promotes cell proliferation and functions as a cancer promoter (38). Previous studies found that NF- $\kappa \mathrm{B}$ and its gene product cyclin $\mathrm{D} 1$ are also involved in the proliferation-promoting effect of $\mathrm{Reg} 3 \mathrm{~A}$ on $\mathrm{PaC}$ cells $(5,6)$. Therefore, Reg3A upregulates the NF- $\mathrm{KB} /$ cyclin D1 signaling pathway and interacts with the JAK2/STAT3 pathway to create a positive feedback loop to promote $\mathrm{PaC}$ development and progression. Treatment with eckol resulted in a significant suppression of Reg3A-upregulated the expression of JAK2, STAT3, NF- $\kappa B$ and cyclin D1 in SW1990 PaC cells. We therefore hypothesized that eckol may exert its protective activity against Reg3A-incduced SW1990 cell proliferation, at least partly, by inhibition of JAK/STAT3 and NF- $\mathrm{BB} /$ cyclin D1 signaling pathways. 
In summary, in the SW1990 PaC cells, eckol exerted a protective effect on $\mathrm{PaC}$ cells from Reg3A-induced proliferation in a concentration-dependent manner, which was observed by the reduction of Reg3A-promoted cell survival and attenuation of Reg3A-induced cell cycle progression in the Reg3A-stimulated cells co-treated with eckol. In addition, colony growth of SW1990 PaC cells in soft agar was significantly increased in the presence of exogenous Reg3A, which was reversed by the addition of eckol and the expression levels of JAK2, STAT3, NF- $\mathrm{B}$ and cyclin D1 were upregulated following treatment with Reg3A, and these were reversed when co-treated with eckol. Therefore, the Reg3A associated JAK/STAT3 and NF- $\mathrm{KB} /$ cyclin D1 signaling pathways may be involved in the protective effect of eckol on Reg3A-induced proliferation of SW1990 PaC cells. As $\mathrm{Reg} 3 \mathrm{~A}$ is as a protein upregulated during pancreatic inflammation with pro-growth functions, it serves an important role during inflammation-driven $\mathrm{PaC}$ malignancies, and the above results support the notion that eckol may be used as a potential protective agent against progression of $\mathrm{PaC}$ accompanied by pancreatic inflammation. However, the protective effects of eckol on the proliferation of $\mathrm{PaC}$ cells induced by other pro-proliferative factors other than Reg3A still require further study, to determine whether eckol effects are limited to the activity of Reg3A or not.

\section{Acknowledgements}

Not applicable.

\section{Funding}

The present study was funded by The National Natural Science Foundation of China (grant no. 81602108).

\section{Availability of data and materials}

The datasets used and/or analyzed during the current study are available from the corresponding author on reasonable request.

\section{Authors' contributions}

JW designed the study, conducted the experiments and wrote the manuscript. MZ and WZ collected the data and performed the experiments. SZ, SL and DY performed data analysis. MZ and $\mathrm{WZ}$ revised the manuscript. All authors collaborated to develop the manuscript.

\section{Ethics approval and consent to participate}

Not applicable.

\section{Patient consent for publication}

Not applicable.

\section{Competing interests}

The authors declare that they have no competing interests.

\section{References}

1. Ma Y, Wu Q, Li X, Gu X, Xu J and Yang J: Pancreatic cancer: From bench to bedside. Ann Transl Med 4: 458, 2016.

2. Siegel RL, Miller KD and Jemal A: Cancer statistics, 2016. CA Cancer J Clin 66: 7-30, 2016.

3. Xu Q, Fu R, Yin G, Liu X, Liu Y and Xiang M: Microarray-based gene expression profiling reveals genes and pathways involved in the oncogenic function of REG3A on pancreatic cancer cells. Gene 578: 263-273, 2016.

4. Li Q, Wang H, Zogopoulos G, Shao Q, Dong K, Lv F, Nwilati K, Gui XY, Cuggia A, Liu JL and Gao ZH: Reg proteins promote acinar-to-ductal metaplasia and act as novel diagnostic and prognostic markers in pancreatic ductal adenocarcinoma. Oncotarget 7: 77838-77853, 2016.

5. Liu X, Wang J, Wang H, Yin G, Liu Y, Lei X and Xiang M: REG3A accelerates pancreatic cancer cell growth under IL-6-associated inflammatory condition: Involvement of a REG3A-JAK2/STAT3 positive feedback loop. Cancer Lett 362: 45-60, 2015.

6. Wang J, Zhou H, Han Y, Liu X, Wang M, Wang X, Yin G, Li X and Xiang M: SOCS3 methylation in synergy with Reg3A overexpression promotes cell growth in pancreatic cancer. J Mol Med (Berl) 92: 1257-1269, 2014.

7. Chen ZF, Huang ZM, Xue HB, Lin XQ, Chen RP, Chen MJ and Jin RF: REG3A promotes the proliferation, migration, and invasion of gastric cancer cells. Onco Targets Ther 10: 2017-2023, 2017.

8. Ye Y, Xiao L, Wang SJ, Yue W, Yin QS, Sun MY, Xia W, Shao ZY and Zhang H: Up-regulation of REG3A in colorectal cancer cells confers proliferation and correlates with colorectal cancer risk. Oncotarget 7: 3921-3933, 2016.

9. Fukushima N, Koopmann J, Sato N, Prasad N, Carvalho R, Leach SD, Hruban RH and Goggins M: Gene expression alterations in the non-neoplastic parenchyma adjacent to infiltrating pancreatic ductal adenocarcinoma. Mod Pathol 18: 779-787, 2005.

10. Xie MJ, Motoo Y, Iovanna JL, Su SB, Ohtsubo K, Matsubara F and Sawabu N: Overexpression of pancreatitis-associated protein (PAP) in human pancreatic ductal adenocarcinoma. Digest Dis Sci 48: 459-464, 2003.

11. Yue Q, Gao G, Zou G, Yu H and Zheng X: Natural products as adjunctive treatment for pancreatic cancer: Recent trends and advancements. Biomed Res Int 2017: 8412508, 2017.

12. Marasini B and Sahu RP: Natural anti-cancer agents: Implications in gemcitabine-resistant pancreatic cancer treatment. Mini Rev Med Chem 17: 920-927, 2017.

13. Li Y, Fu X, Duan D, Liu X, Xu J and Gao X: Extraction and identification of phlorotannins from the brown alga, sargassum fusiforme (Harvey) setchell. Mar Drugs 15: pii: E49, 2017.

14. Kang MC, Cha SH, Wijesinghe WA, Kang SM, Lee SH, Kim EA, Song CB and Jeon YJ: Protective effect of marine algae phlorotannins against AAPH- induced oxidative stress in zebrafish embryo. Food Chem 138: 950-955, 2013.

15. Lee MS, Shin T, Utsuki T, Choi JS, Byun DS and Kim HR: Isolation and identification of phlorotannins from Ecklonia stolonifera with antioxidant and hepatoprotective properties in tacrine-treated HepG2 cells. J Agric Food Chem 60: 5340-5349, 2012.

16. Kim AD, Kang KA, Piao MJ, Kim KC, Zheng J, Yao CW, Cha JW, Hyun CL, Kang HK, Lee NH and Hyun JW: Cytoprotective effect of eckol against oxidative stress-induced mitochondrial dysfunction: Involvement of the FoxO3a/AMPK pathway. J Cell Biochem 115: 1403-1411, 2014.

17. Jung HA, Kim JI, Choung SY and Choi JS: Protective effect of the edible brown alga Ecklonia stolonifera on doxorubicin-induced hepatotoxicity in primary rat hepatocytes. J Pharm Pharmacol 66: 1180-1188, 2014.

18. Ahn BR, Moon HE, Kim HR, Jung HA and Choi JS: Neuroprotective effect of edible brown alga Eisenia bicyclis on amyloid beta peptide-induced toxicity in PC12 cells. Arch Pharm Res 35: 1989-1998, 2012.

19. Kang SM, Cha SH, Ko JY, Kang MC, Kim D, Heo SJ, Kim JS, Heu MS, Kim YT, Jung WK and Jeon YJ: Neuroprotective effects of phlorotannins isolated from a brown alga, Ecklonia cava, against $\mathrm{H} 2 \mathrm{O} 2$-induced oxidative stress in murine hippocampal HT22 cells. Environ Toxicol Pharmacol 34: 96-105, 2012.

20. Jung HA, Roy A, Jung JH and Choi JS: Evaluation of the inhibitory effects of eckol and dieckol isolated from edible brown alga Eisenia bicyclis on human monoamine oxidases A and B. Arch Pharm Res 40: 480-491, 2017. 
21. Jung HA, Jung HJ, Jeong HY, Kwon HJ, Ali MY and Choi JS Phlorotannins isolated from the edible brown alga Ecklonia stolonifera exert anti-adipogenic activity on 3T3-L1 adipocytes by downregulating $\mathrm{C} / \mathrm{EBP} \alpha$ and PPAR $\gamma$. Fitoterapia 92: 260-229, 2014.

22. Jung HA, Jin SE, Ahn BR, Lee CM and Choi JS: Anti-inflammatory activity of edible brown alga Eisenia bicyclis and its constituents fucosterol and phlorotannins in LPS-stimulated RAW264. 7 macrophages. Food Chem Toxicol 59: 199-206, 2013.

23. Kang YM, Eom SH and Kim YM: Protective effect of phlorotannins from Eisenia bicyclis against lipopolysaccharide-stimulated inflammation in HepG2 cells. Environ Toxicol Pharmacol 35: 395-401, 2013

24. Noda H, Amano H, Arashima K, Hashimoto S and Nisizawa K: Studies on the antitumor activity of marine algae. Nippon Suisan Gakk 55: 1259-1264, 1989.

25. Hyun KH, Yoon CH, Kim RK, Lim EJ, An S, Park MJ, Hyun JW, Suh Y, Kim MJ and Lee SJ: Eckol suppresses maintenance of stemness and malignancies in glioma stem-like cells. Toxicol Appl Pharmacol 254: 32-40, 2011.

26. Ochoa JJ, Farquharson AJ, Grant I, Moffat LE, Heys SD and Wahle KW: Conjugated linoleic acids (CLAs) decrease prostate cancer cell proliferation: Different molecularmechanisms for cis-9, trans-11 and trans-10, cis-12 isomers. Carcinogenesis 25: 1185-1191, 2004.

27. Schmittgen TD and Livak KJ: Analyzing real-time PCR data by the comparative C(T) method. Nat Protoc 3: 1101-1108, 2008.

28. Pesic M and Greten FR: Inflammation and cancer: Tissue regeneration gone awry. Curr Opin Cell Biol 43: 55-61, 2016.

29. Hamada S, Masamune A and Shimosegawa T: Inflammation and pancreatic cancer: Disease promoter and new therapeutic target. J Gastroenterol 49: 605-617, 2014.
30. Gukovsky I, Li N, Todoric J, Gukovskaya A and Karin M: Inflammation, autophagy, and obesity: Common features in the pathogenesis of pancreatitis and pancreatic cancer. Gastroenterology 144: 1199-1209, 2013.

31. Zambirinis CP, Pushalkar S, Saxena D and Miller G: Pancreatic cancer, inflammation, and microbiome. Cancer J 20: 195-202, 2014.

32. Zhao X, Fan W, Xu Z, Chen H, He Y, Yang G, Hu H, Tang S, Wang P, Zhang Z, et al: Inhibiting tumor necrosis factor-alpha diminishes desmoplasia and inflammation to overcome chemoresistance in pancreatic ductal adenocarcinoma. Oncotarget 7: 81110-81122, 2016

33. Piao MJ, Lee NH, Chae S and Hyun JW: Eckol inhibits ultraviolet B-induced cell damage in human keratinocytes via a decrease in oxidative stress. Biol Pharm Bull 35: 873-880, 2012.

34. Kang KA, Lee KH, Chae S, Zhang R, Jung MS, Lee Y, Kim SY, Kim HS, Joo HG, Park JW, et al: Eckol isolated from Ecklonia cava attenuates oxidative stress induced cell damage in lung fibroblast cells. FEBS Lett 579: 6295-6304, 2005.

35. Harada D, Takigawa N and Kiura K: The Role of STAT3 in non-small cell lung cancer. Cancers (Basel) 6: 708-722, 2014

36. Karin M: Nuclear factor-kappaB in cancer development and progression. Nature 441: 431-436, 2006.

37. Grivennikov SI and Karin M: Dangerous liaisons: STAT3 and NF-kappaB collaboration and crosstalk in cancer. Cytokine Growth Factor Rev 21: 11-19, 2010

38. Ledoux AC and Perkins ND: NF- $\mathrm{BB}$ and the cell cycle. Biochem Soc Trans 42: 76-81, 2014.

(i) (9) This work is licensed under a Creative Commons

EY No NO Attribution-NonCommercial-NoDerivatives 4.0 International (CC BY-NC-ND 4.0) License. 